\title{
IMANDT EN MOOI INDIË VOORBIJ \\ 'Wie Indië Schilderen wil, moet er lang blijven'
}

In dit artikel zal tegen de achtergrond van opvattingen over de schilderkunst in Nederlands-Indië in de eerste helft van de $20^{\mathrm{e}}$ eeuw de kunstenaar W.J.F. Imandt (1882-1967) die er ruim 20 jaar woonde, voor het voetlicht worden gebracht. Ik hoop erin aan te tonen dat de zogenoemde 'Mooi Indië'/ Indische schilderkunst ten onrechte door kunsthistorici op het terrein van kunst in Indonesië in de eerste helft van de $20^{e}$ eeuw is genegeerd en gedenigreerd. Iedereen die niet in hun canon van academisch opgeleide kunstenaars viel, werd onder de noemer Mooi Indië geschoven en afgedaan. Dat geldt ook voor Imandt, over wie nauwelijks iets bekend was. Gelukkig is er veel werk van hem in privécollecties bewaard gebleven. Het biedt inzicht in zijn schilderkunstige ontwikkeling waarin de Mooi Indië stijl sec een korte periode beslaat en niets te maken heeft met het containerbegrip dat van Mooi Indië is gemaakt. Mijn onderzoek naar Willem Imandt zal binnen afzienbare tijd uitmonden in een monografie.

\section{Toenemende belangstelling}

De hoeveelheid publicaties over beeldende kunst in Nederlands-Indië houdt meer dan gelijke tred met de sinds eind jaren 1980 toegenomen belangstelling voor buitenlandse kunstenaars die in Indonesië hebben gewerkt. Die interesse wordt gevoed door welvarende Indonesiërs die de doeken van Westerse schilders uit de koloniale tijd zijn gaan waarderen. De veilingwereld heeft er op ingespeeld met veilingen van 'Indonesische' kunst, en galerieën in Indonesië exposeren regelmatig schilderijen die uit de koloniale tijd stammen. In het land van de voormalige kolonisator is die interesse, gedreven door de oud-Indiëgangers, nooit helemaal weg geweest en heeft de laatste 20 jaar zelfs een grote vlucht genomen. Ook de Nederlandse musea werden actief en hun perspectief verschoof van het koloniale naar dat van wederzijdse culturele beïnvloeding. Grensverleggend in dat opzicht was de tentoonstelling Indië Omlijst. Vier eeuwen schilderkunst in Nederlands-Indië in het Tropenmuseum (1998), die een omslagpunt in die wederzijdse appreciatie markeerde, waarvan de contouren overigens vanaf begin jaren 1960 zichtbaar werden.

\section{Hernieuwde appreciatie}

Die appreciatie kwam tot uitdrukking in de monumentale vijfdelige uitgave Paintings and Statues from the Collection of President Sukarno of the Republic of Indonesia (1964). Centraal staat het werk van Indonesische kunstenaars, maar Westerse kunstenaars ontbreken niet. Imandt bijvoorbeeld is met vijf werken goed in die collectie vertegenwoordigd. De uitgave kan gezien worden als de klaroenstoot tot de herleving vande belangstelling voor in Indonesie $22: 48 \mathrm{PM}$ gemaakte schilderkunst. In 1967 verscheen Pictures of the Tropics van de ${ }^{\text {ee }}$ access 
Afb. 2

Willem Imandt,

Berglandschap, olieverf op doek, $80 \times 60 \mathrm{~cm}$.,

ca. 1935

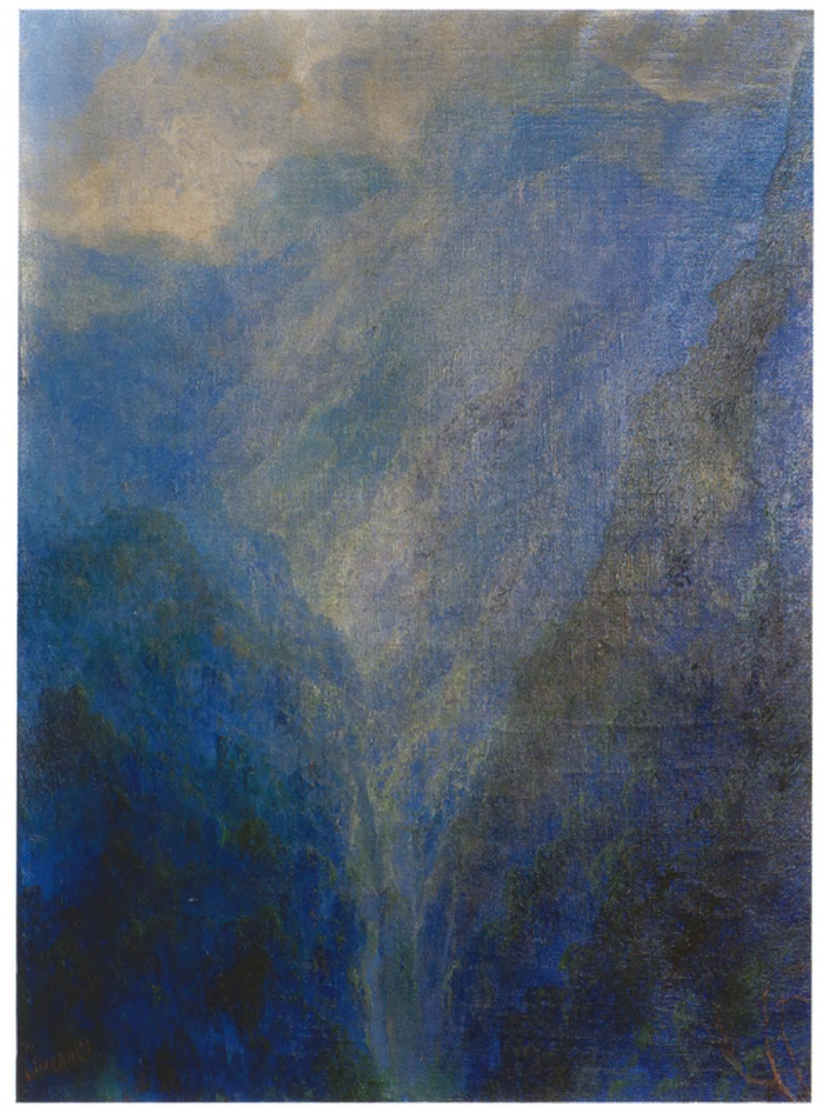

hand van J.H. Maronier, waarin Nederlands-Indië centraal staat. Een jaar later verscheen het baanbrekende werk van J. de Loos-Haaxman, Verlaat Rapport Indië. Drie eeuwen Westerse schilders, tekenaars, grafici, zilversmeden en kunstnijveren in Nederlands-Indië. De Loos-Haaxman was door haar werk als conservator van de Bataviasche Kunstkring tijdgenoot van Imandt, en zij noemt hem als eerste in een opsomming van Nederlandse kunstenaars in Indië omdat hij in de jaren 1920 de bekendste schilder op Java was. ${ }^{2}$ Tien jaar later verscheen de klassieker van J. Bastin en B. Brommer, Nineteenth century prints and illustrated books of Indonesia (1979). In 1995 gaven de kunsthandelaren L. Haks en G. Maris het handige Lexicon of Foreign Artists who visualized Indonesia (1600-1950) uit dat een overzicht biedt van de meer dan 3000 buitenlandse beeldende kunstenaars die in Indonesië werkzaam zijn geweest. Het rijk geïllustreerde werk bevat meer dan 600 afbeeldingen die een gevarieerd beeld geven van meer dan drie eeuwen schilderen en tekenen in de Archipel.

\section{Canonisatie}

Drie jaar later verscheen de publicatie Indië Omlijst (1998), met een inventarisatielijst van meer dan 400 olieverfschilderijen uit het Tropenmuseum. Voor het overige zijn er de laatste 20 jaar monografieën van sterk wisselende kwaliteit verschenen over kunstenaars die in de eerste helft van de $20^{\mathrm{e}}$ eeuw in Nederlands-Indië werkten, maar die geen vann allen Mooi Indië schilders $22: 48 \mathrm{PM}$ waren. $\mathrm{Zij}$ behoorden allen tot de groep kunstenaars die in de loop der jarenccess 
door kunsthistorici tot de canon zijn gerekend, zoals onder andere Walter Spies, Rudolf Bonnet, Adolf Breetvelt, Pieter Ouburg, Charles Sayers, en Isaac Israëls.

Volgens de kunsthistoricus Koos van Brakel '[...] they transcended the general conservatism in East Indies painting. They were aware of developments in the European art world and a number of them [...] had academic backgrounds' ${ }^{3}$ Voor de grap noem ik ze wel eens 'Niet Mooi Indië schilders' om ze te onderscheiden van de Mooi Indië schilders. Tot de andere groep schilders, zonder academische achtergrond, behoorden volgens Van Brakel, Leonard Eland, Ernest Dezentjé en Carel Dake. Imandt noemde hij toen nog niet. ${ }^{4}$ Of deze Mooi Indië schilders op de hoogte waren van ontwikkelingen in de Europese kunst laat hij in het midden, maar hij suggereert van niet en laat blijken dat zijn voorkeur naar de Niet Mooi Indië schilders uitgaat.

\section{Mooi Indië vervloekt}

De kunstcriticus J. Tielrooy schreef in 1930 een artikel dat tot op de dag van vandaag aangehaald wordt, 'Indië in de schilder- en teekenkunst'. Hij richtte zijn venijnige pijlen op Dezentjé:

Wie zou Ernest Dezentjé niet kennen? [...] Dezentjé schildert sawah's en het water is zilverblinkend, de dijkjes zijn groen; op den achtergrond zet hij een berg en de berg, men kan er vast op rekenen, is donkerblauw; de vereischte palm is aanwezig, en aan het uitspansel in de verte smelten smachtende gelen met poëtisch rood tezamen. ${ }^{5}$

De bijtende kritiek op de Mooi Indië schilders in zijn artikel doet zijn giftige werking tot op heden gelden.

Die kritiek deed de vraag naar hun werk niet verminderen. Zowel bij toeristen en Indië-gangers als bij hooggeplaatste Javanen en welvarende Chinezen vond hun werk gretig aftrek. Anders dan de academisch gevormde schilders die meestal niet lang in Nederlands-Indië bleven, waren de Mooi Indië schilders veel meer met dat land vervlochten, ofwel door geboorte (Eland en Dezentjé hadden Indisch bloed), of door hun werk, zoals Imandt. Kan het niet zo zijn dat de Niet Mooi Indië schilders met hun hoofd in Europa bleven en kubistische of surrealistische voorstellingen in Indië maakten, terwijl de Mooi Indië schilders, omdat ze er thuis waren, thema's in hun werk neerzetten die Javaans zijn?

\section{Schilderthema's}

Thema's zijn vooral het landschap en de bevolking. Bij het laatste ging het vooral om volkstypes, bij voorkeur Javaanse en Balinese vrouwen met ontbloot bovenlijf, of mannen met nauwelijks verhullende lapjes om. Naakt gold lange tijd als onzedelijk, behalve als het exotisch was. Talloze huiskamers in Nederland werden met deze zoetsappige, licht prikkelende kitsch getooid. Imandt liet dit thema links liggen en concentreerde zich op het tweede grote thema: het landschap. Dat maakt niet alleen diepe indruk op de Europeaan. De bergen worden zowel in boeddhisme als hindoeïsme gezien als spiritueel geladen plekken waar contact tussen de goden-en mensen- $n_{-2: 22: 48 \mathrm{PM}}$ wereld mogelijk is. In de hoedanigheid van mediator tussen deze wereldren access 


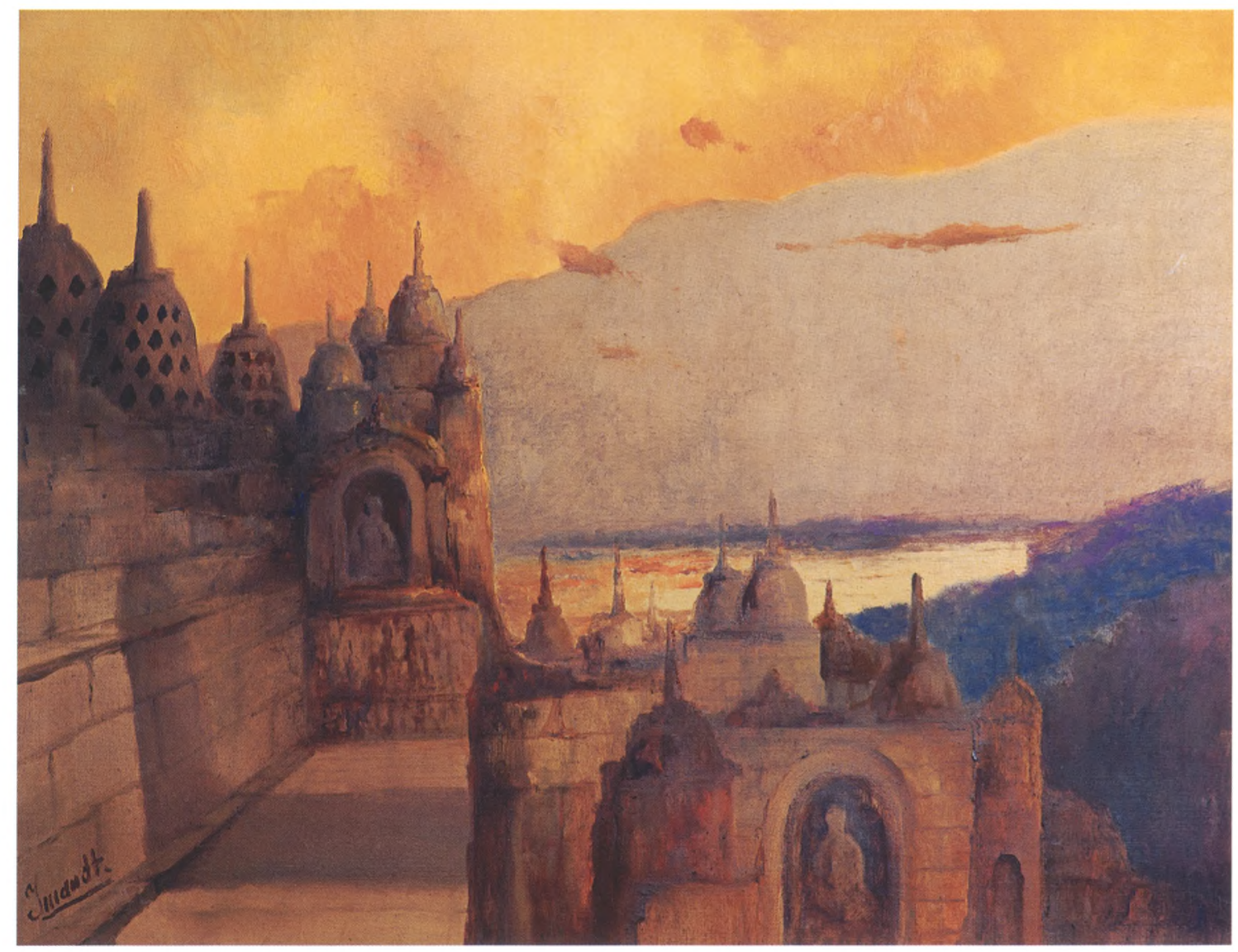

Afb. 3

Willem Imandt,

Borobudur bij ondergaande zon, olieverf op doek, $60 \times 80 \mathrm{~cm}$., ca. 1920 de hemelse, speelden de bergen en vulkanen, maar ook bomen zoals de waringin, een centrale rol in de belevingswereld van de Javaan.

Wilden de Mooi Indië schilders als zij een berg schilderen niet het idee van de berg vatten en daarmee hun spirituele en persoonlijk band met Indonesië vastleggen? Imandt zelf maakt duidelijk dat hij vooral uit praktische overwegingen de door de kritiek gewraakte doeken maakte. Hij schilderde het liefst andere werken en conformeerde zich bepaald niet altijd aan de smaak van het Indische publiek. Hij is de enige in Nederlands-Indië werkende schilder die ooit een korte verhandeling over het schilderen daar schreef (zie ook pagina $15 \mathrm{t} / \mathrm{m} \mathrm{17):}$

"Op een Indisch doek moeten klapperboomen en sawah's voorkomen". Hoe vaak wordt ons dit niet als een zacht verwijt toegevoegd! Ik geef evenwel alle klappers en sawah's voor één Indischen woudreus. Zeker, ik heb onnoemlijk veel klappers en sawah's op het doek gebracht want ook een schilder moet op stuk van zaken leven en geld verdienen. $^{6}$ 
Afb. 4

Willem Imandt, Het meer van Cangkuang Nera Leles bij Garut (Java), olieverf op doek, $35 \times 45$ cm., ca. 1923

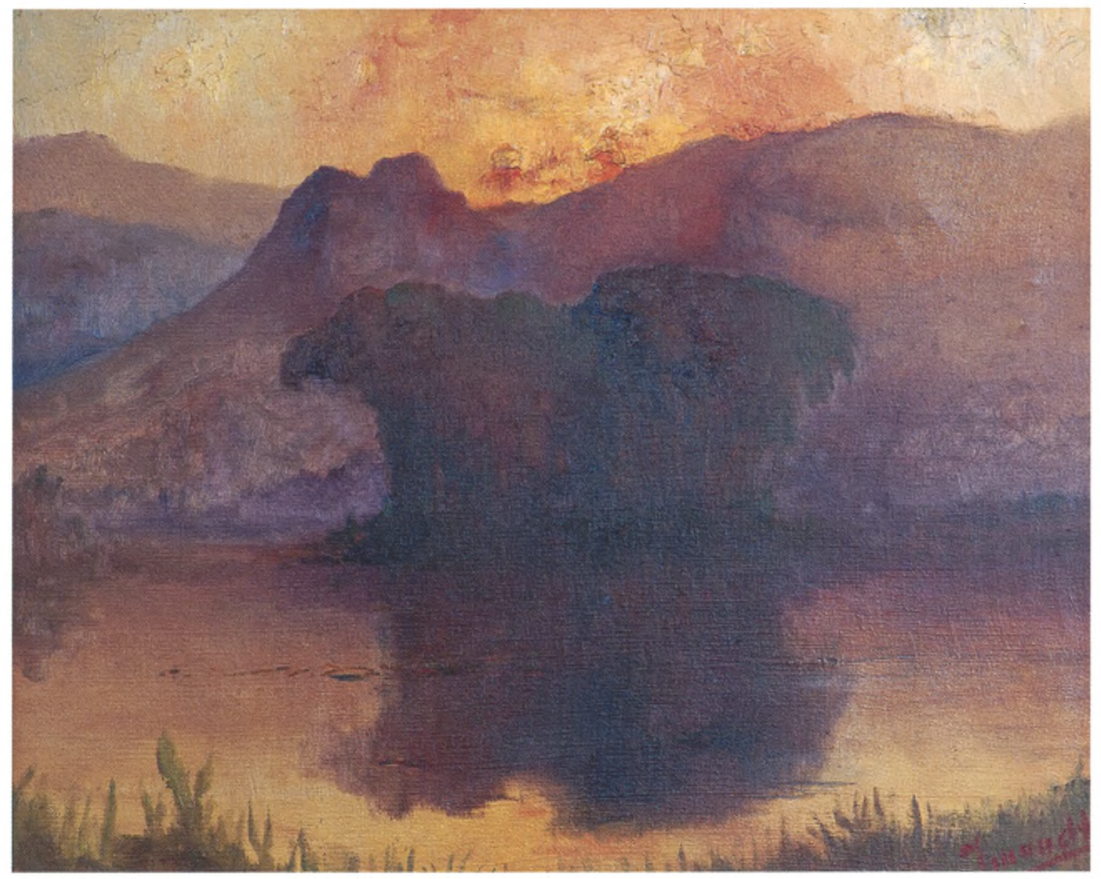

Afb. 5

Willem Imandt,

Meer op Java, olieverf op doek, $80 \times 100 \mathrm{~cm}$., ca. 1920 
in Amsterdam verliefd was geworden op de Friese zangeres Eliza Robijns ging hij daar weer aan de slag. In 1908 solliciteerde Willem op een onderwijzersbaan in Nederlands-Indië. Het was een aantrekkelijk perspectief en een uitdaging tegelijkertijd. Hij werd aangenomen en nadat ze getrouwd waren, vertrokken Eliza en Willem per oceaanstomer eerste klasse naar de bloeiende kolonie, die vrije kunstenaars steeds meer mogelijkheden bood door het uitdijend netwerk van kunstkringen op Java. ${ }^{7}$

\section{De Reflector als Mooi Indië platform}

Willem Imandt gaf eerst les op Celebes en uit deze tijd stammen zijn eerste Indische doeken. Hier werd in 1910 de eerste zoon geboren van een gezin dat in de loop der jaren uitgroeide tot zes kinderen. In dat jaar werd hij benoemd als onderwijzer aan de openbare Hollands-Chinese school in Yogyakarta.

Afb. 7

Willem Imandt, Meer op Java, olieverf op doek, $83 \times 61,5 \mathrm{~cm}$., ca. 1925

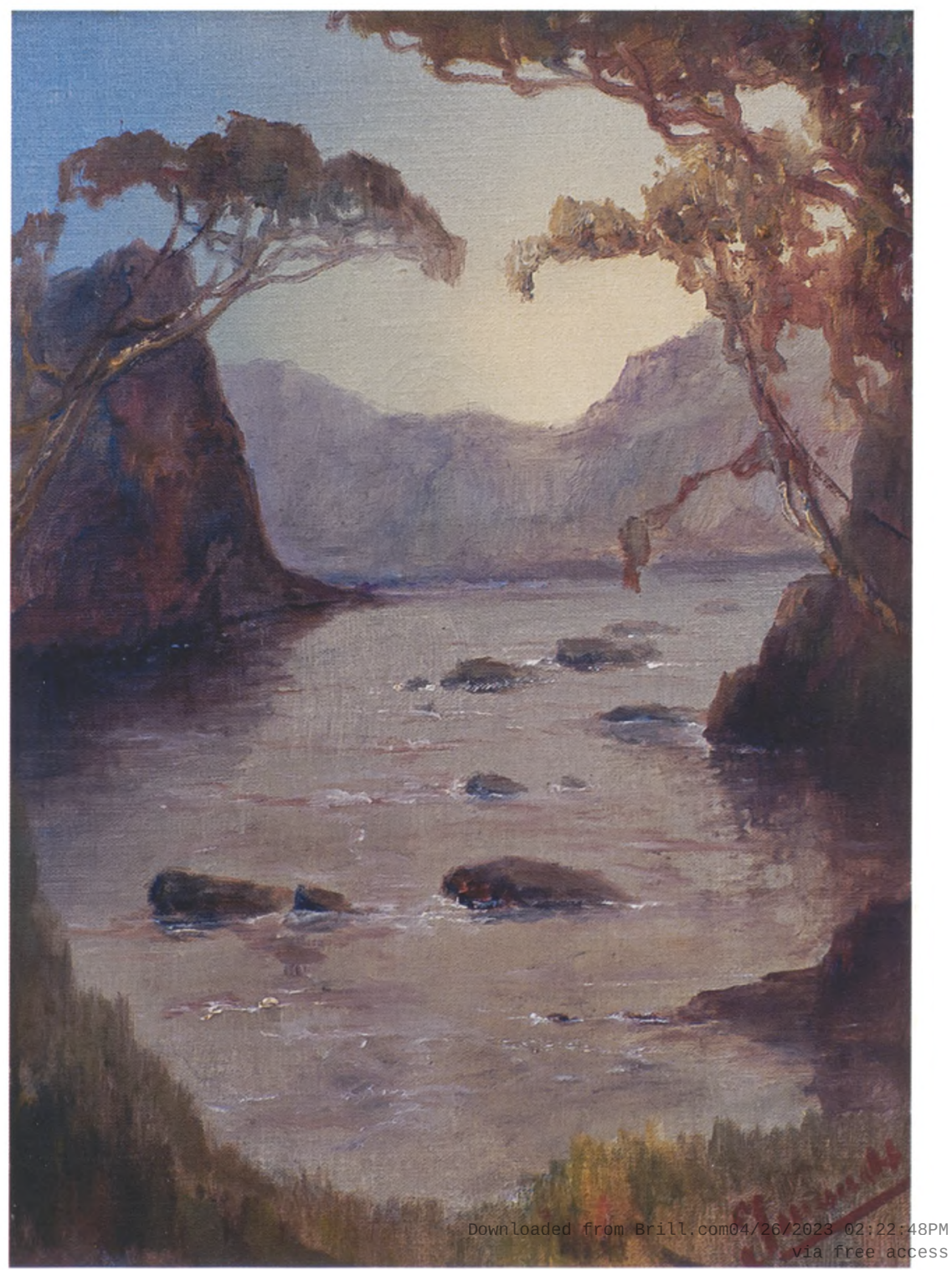


In 1916 nam hij ontslag uit de koloniale dienst en tot zijn pensionering, in 1929 op 47-jarige leeftijd (tropenjaren telden dubbel), was hij hoofdonderwijzer en tekenleraar bij het katholiek onderwijs in Nederlands-Indië.

In deze periode trad hij voor het eerst naar buiten met zijn schilderwerken die hij aan de hand van schetsen uit de natuur altijd in zijn atelier vervaardigde, van meren, ravijnen, bergen, rotskusten, vulkanen en antieke gebouwen zoals de Borobudur. De eerste recensie van zijn werk gaat over een tentoonstelling in Yogyakarta. 'De schilder Imandt, berucht om zijn avondluchten, en bergen kan stilzwijgend worden voorbijgegaan'. ${ }^{8}$ Inderdaad lieten kleurgebruik en compositie nog veel te wensen over. In 1919 verscheen er een artikel over Imandt in het populaire tijdschrift De Reflector. 'Aangemoedigd door onze schitterende foto's van MOOI INDIË heeft de bekende schilder Imandt ons eenige afdrukken gezonden van zijn olieverfschilderijen, voorstellende Mooi Indië'. ${ }^{9} \mathrm{Hij}$ wordt door de auteur van het artikel een harde werker genoemd, die met talent de 'prachtige Indische landschappen heeft bestudeerd'. Dat het een lange studie vereiste werd later door Imandt zelf verwoord: 'Wie Indië schilderen wil, moet er lang blijven. Indië pakt ons op het eerste gezicht, maar laat zich pas pakken als men er jarenlang vertoefd heeft'. ${ }^{10}$ De Reflector wilde met zijn rubriek Mooi Indië de belangstelling van het Indische publiek opwekken voor kunst van eigen (Indische) bodem. Daarom kan het als platform en naamgever worden beschouwd worden voor de Mooi Indië schilders zoals Dake, Dezentjé, Eland en Imandt die in de jaargangen tussen 1916 en 1920 veelvuldig afgebeeld werden. Hun op de natuur van Indonesië gebaseerde kunst vertoonde in thematiek en stijl grote overeenkomsten. Het was dus zeker geen school, maar eerder een groepering die door het (lezers)publiek met elkaar geassocieerd werd, en die niet meer dan vier jaar heeft geduurd. Eland vertrok in 1920 naar Den Haag en Dake keerde zich van de natuurthematiek af. Dezentjé bleef de thematiek tot het eind van zijn leven trouw. Dat gold ook voor Imandt, al zou hij een duidelijk eigen stijl ontwikkelen. In de latere literatuur worden ze dikwijls in een adem én in denigrerende zin genoemd. Alles wat niet bij de canon aansloot werd gemakshalve op de hoop Mooi Indië geveegd.

\section{Bataviasche Kunstkring}

Een week na het artikel in De Reflector stelde een recensent in het Weekblad voor Indië zijn mening over Imandt in positieve zin bij:

Het is ongetwijfeld knap werk en het wil ons voorkomen, dat Imandt, van wien we ons enkele jaren terug een tentoonstelling in den Djokjaschen Sociëteit herinneren, flink vooruit gegaan is in dien tijd. Toen miste zijn werk nog alles, wat naar kracht en durf zweemde - dat alles is thans echter geheel anders geworden. ${ }^{11}$

Afgebeeld in het Weekblad zijn Mangrovebos aan het strand en Rotskust. In Mangrovebos kondigt zich al zijn voorliefde voor bomen aan, die hij steeds meer pasteus zou schilderen. Vergelijkbare rotskusten, waarvan er de nodige in omloop zijn, kunnen voor 1920 gedateerd worden.

Uit de recensie blijkt dat Imandt in korte tijd respect had weten af te dwingen. Het summum van erkenning voor een in Nederlands-Indië werkende kunstenaar was gevraagd te worden voor de jaarlijkse augustus-tentoonstelling van de in 1902 opgerichte Bataviasche Kunstkring. Imandt maakte er zijndebuutcess 


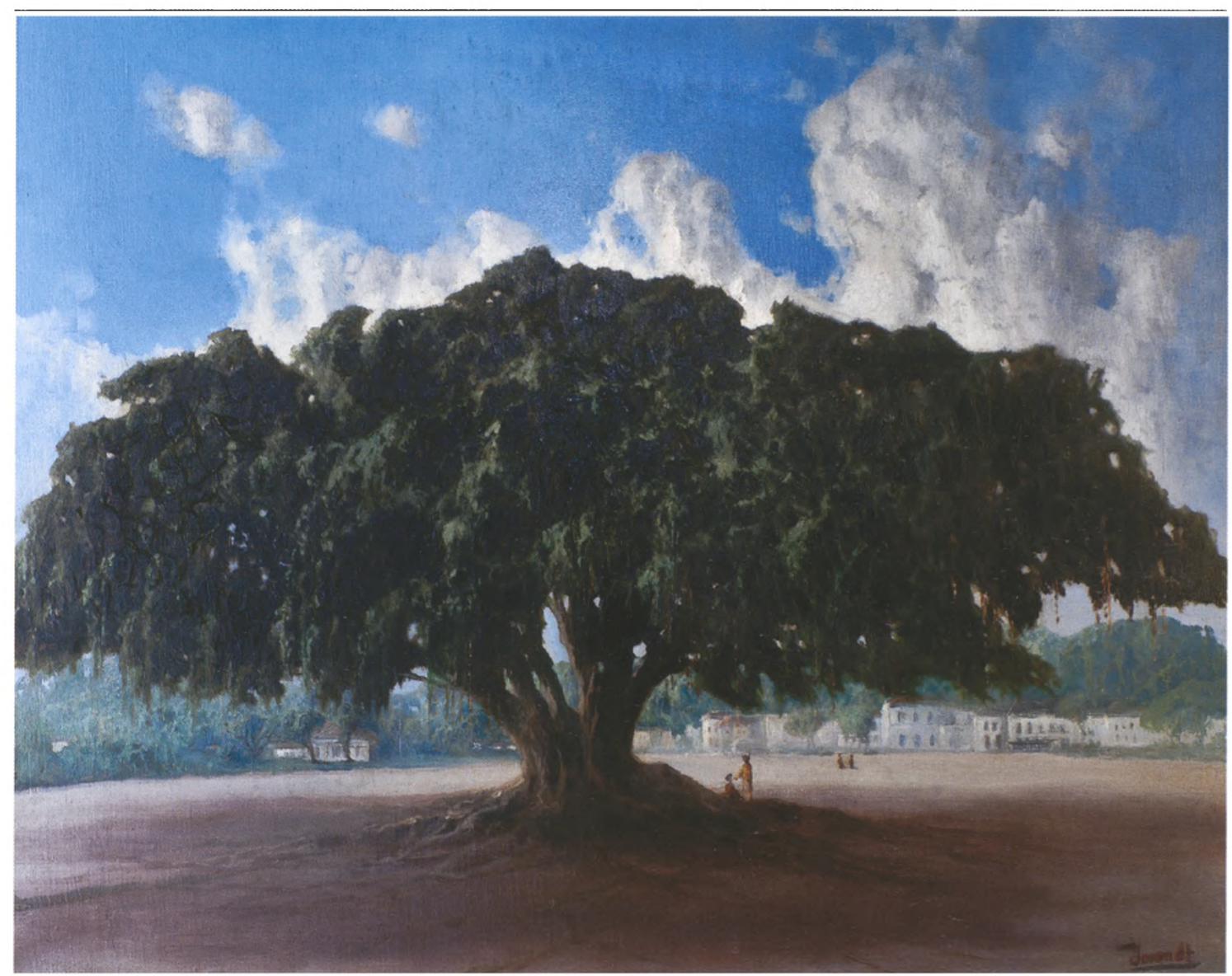

Afb. 8

Willem Imandt, Waringin, olieverf op doek, $90 \times 105 \mathrm{~cm}$., ca. 1923. Volgens de overlevering zouden de figuren door Isaac Israěls zijn geschilderd die in 1923 dikwijls bij Imandt op bezoek kwam. in augustus 1920. Er waren in totaal 20 exposanten. Dat Imandt in 1920 al een bekende kunstenaar was, wordt ook bevestigd door de hoge prijzen voor zijn werk. Voor een klein doek werd 150 gulden gevraagd en voor grotere werken 450 gulden. Wanneer de recensent van de Javabode langs het werk van Imandt loopt, overvalt hem 'niet alleen een gevoel van kalmte', maar tegelijkertijd vindt hij het 'fraaie doeken, waarvan vooral de luchten imponeren.'12 Imandt exposeerde er tot 1925 een hele waaier aan onderwerpen: van vulkanen en bergen tot meren en zeeën, van bomen tot ruïnes. Zijn werk bleef onverminderd gewaardeerd.

\section{Imandt de Grote Schilder hier!}

In 1922 ontmoette hij in Solo de in impressionistische trant werkende schilder Isaac Israëls. Zij zagen elkaar in die periode frequent. In Israëls laatste brief, voor vertrek naar Nederland, aan de schilder Willem Witsen bleek het wel eens te veel. 'Overigens is hier dan ook niemand. Je snakt wel eens naar iemand anders dan Imandt de Grote Schilder hier!'. ${ }^{13}$ Afgezien van de flauwe woordspeling bevat Israëls opmerking $\boldsymbol{o o k}_{\mathrm{n}}$ een zekere jolousie de 22 : 48PM metier, want terwijl Israëls in Nederland een halfgod was, betekende hij in in access 
Nederlands-Indië in tegenstelling tot de Grote Schilder weinig. Volgens Imandts dochter werkten ze samen aan een schilderij. Willem schilderde de waringin en Isaac de figuren (afb. 8). De schilderijen van waringins behoren zonder meer tot de hoogtepunten van Imandts Nederlands-Indische oeuvre. Imandt stond op het hoogtepunt van zijn roem. De zwager van koningin Wilhelmina, de hertog van Mecklenburg en de heer Han, leider van de Chinezen in Batavia, bezochten in 1923 zijn atelier en bestelden doeken. 'Wij waren in de gelegenheid zijn hoogst artistieke en kleurrijke werken uit de schoone natuur van de Preanger en elders, te bezichtigen en hoogelijk te waarderen'.${ }^{14}$ Imandt vond in H. Bos in Den Haag een gerespecteerde kunsthandel die zijn werken ging verkopen. De laatste twee jaar verbleef Imandt in het mondaine en westers georiënteerde Bandung, waar hij niet langer als hoofdonderwijzer maar als kunstschilder in het telefoonboek stond genoteerd. Bij Imandts terugkeer naar Europa in 1929 pakte Bos uit met een solotentoonstelling die vier maanden duurde en waar veel werk werd verkocht. ${ }^{15}$ Imandt vertrok eind juni met zijn gezin naar Sint-Gillis-Waas, enige kilometers van zijn geboorteplaats in België, waar hij een fraai huis met atelier betrok dat hij Insulinde doopte. Kortom, Imandt kwam als een gefortuneerd man terug uit Nederlands-Indië waar hij een van de bekendste Westerse schilders was geworden.

\section{In het Land van Waas en Insulinde}

Hij kon zich nu volledig op zijn werk concentreren. Zijn voornaamste onderwerp bleef Indië, maar door reizen rond de Middellandse Zee kregen sommige doeken een oriëntalistische inslag. Hij leefde een vrij teruggetrokken bestaan en verkocht vooral schilderijen aan kennissen en familie in zijn geboortestreek. Pas in 1935 ontdekte een Vlaamse journalist de 'Indische schilder' die toen op het hoogtepunt van zijn kunnen stond. Hoofdreden voor zijn terugkeer was de scholing van zijn zoons en dochters in Nederland. Met de dreiging van een nieuwe wereldoorlog en zijn zoons in de cultures in Nederlands-Indië besloot Imandt in 1938 terug naar Insulinde te keren. Dat was in de tussenliggende 10 jaar sterk veranderd door het toenemende nationalisme. Willem zal daar weinig van gemerkt hebben want hij vestigde zich in de tuinstad Malang. Veel (gepensioneerde) Nederlanders gingen daar wonen, aangetrokken door het aangenaam koele klimaat. Imandt verkocht nog wel werken, maar niet langer nat van de ezel zoals vroeger. Lang duurde de idylle niet want in 1942 werd hij geïnterneerd in een Jappenkamp. Zijn archief ging verloren en in 1946 keerde hij berooid terug naar Nederland, waar hij in Den Haag ging wonen. Hij leefde er van zijn pensioen, maar verkocht ook nog wel incidenteel schilderijen met Indische motieven. In 1954 kreeg hij op 72-jarige leeftijd een overzichttentoonstelling in de zalen van Hoogovens. Een schilder van vulkanen had zich geen beter decor kunnen wensen. De hoofdmoot werd gevormd door zijn Indische doeken.

Het is moeilijk niet poëtisch te zijn bij het aanschouwen van dit deel der aarde, zoals Willem Imandt het ons voortovert, want de kenmerkende sfeer van de tropen, het heldere licht dat aan alle kleuren een bijzonder reliëf verleent, de nuancen van groen, het felle blauw van de tropenhemel, het levende groen van de zee, dit alles weet de schilder met een groot meesterschap op het doek te brengen. Het Oosten leeft yoor ons, gezien door de schildersogen van Imandt. ${ }^{16}$ 
Imandt stierf in 1967 op het dieptepunt van de belangstelling voor schilderkunst uit de voormalige kolonie. De waardering is de laatste 20 jaar echter spectaculair toegenomen, al geldt dat veel minder voor Mooi Indië. Toch lijkt er sprake te zijn van voortschrijdend inzicht. In een recent artikel over de Mooi Indië kunst in de catalogus van de tentoonstelling 'Beyond the Dutch' (2009-10) in het Centraal Museum in Utrecht staat te lezen:

De Indische schilderkunst werd geruime tijd genegeerd en als men er al aandacht aan besteedde dan was dat toch vooral in misprijzende termen [...] De Indische schilderkunst verdient, als onderdeel van de koloniale geschiedenis als gedeeld erfgoed van Nederland en Indonesië, een plaats in de schilderkunst van beide landen. ${ }^{17}$

Ook Van Brakel heeft Imandt ontdekt. Hij haalt in het hierboven genoemde artikel een citaat uit Imandts 'Schilderen in Indië' aan. Daar moet de auteur, medewerker van het Tropenmuseum, zeker Imandts fraaie waringin in de permanente expositie over Nederlands-Indië hebben zien hangen. Hoewel? Het werk hangt in een hoek hoog tegen het plafond, vrijwel onzichtbaar voor de gemiddelde bezoeker.

De Indische schilderkunst verdient niet alleen een plaats in de schilderkunst van beide landen, maar ook een zelfstandige plek. Het heeft een duidelijk eigen cachet, zoals Imandt in zijn artikel opmerkt: 'Het eigen cachet ontleent het Indisch palet aan zijn in het Westen onbestaanbare kleurschakeeringen en overgangen'. ${ }^{18}$ In mijn monografie van Imandt hoop ik aan te tonen dat hij zich via de Mooi Indië schilderkunst heeft ontwikkeld tot een beeldend kunstenaar met een herkenbare signatuur die onovertroffen is in het vastleggen van de magische natuur van Indonesië.

- Dr. Paul van der Velde (1955) studeerde sinologie en geschiedenis in Leiden en Kunstgeschiedenis van Oost-Azië te Amsterdam. Hij schreef onder andere Een Indische liefde: P.J. Veth (1814-1895) en de inburgering van Nederlands Indië (2000) en Wie onder Palmen leeft: De sublieme wereld van Jacob Haafner (2008). Van der Velde is Chief Executive Officer van de International Convention of Asia Scholars (ICAS). Voor meer informatie: www.paulvandervelde.nl

\section{Literatuur}

J. Bastin en B. Brommer, Nineteenth century prints and illustrated books of Indonesia, with particular reference to the print collection of the Tropenmuseum, Amsterdam: A descriptive bibliography, Het Spectrum, Utrecht/Antwerpen, 1979.

Koos van Brakel, et al., Indië omlijst, vier eeuwen schilderkunst in Nederlands-Indië, KIT Publications, Amsterdam, 1998.

Koos van Brakel, Charles Sayers 1901-1943: Pioneer painter in the Dutch East Indies, KIT Publications, Amsterdam, 2004.

Koos van Brakel, '"Mooi Indie"-kunst: een koloniaal medium?' in: Meta Knol, Remco Raben en Kitty Zijlmans (red.), Beyond the Dutch. Indonesië, Nederland en de beeldende kunsten van 1900 tot nu, KIT Publishers en Centraal Museum, Amsterdam-Utrecht, 2009, pp. 50-59.

Willem Imandt, 'Schilderen in Indië', Maandblad yoor Beeldende Kunsten 33 (1926) pp. 338-9. 
Lee Man-Fong (ed.), Paintings and Statues from the Collection of President Sukarno of the Republic of Indonesia, Toppan Printing Co., Tokyo, 1964. (Vijf delen)

J. de Loos-Haaxman, Verlaat Rapport Indië: Drie eeuwen Westerse schilders, tekenaars, grafici, zilversmeden en kunstnijveren in Nederlandsch-Indië, Mouton en Co. Uitgevers, 's Gravenhage, 1968.

J.H. Maronier, Pictures of the Tropics. A catalogue of drawings, water-colours, paintings, and sculptures in the collection of the Royal Institute of Linguistics and Anthropology in Pictures from the tropics: Paintings by Western artists during the colonial period in Indonesia, Nijhoff, 's Gravenhage, 1967. [KITLV].

J. Tielrooy, 'Indië in de schilder- en teekenkunst', Elseviers Geillustreerd Maandblad 80 (1930), pp.1-10.

Paul van der Velde, 'Een Steense meester in wording (deel 1). De jeugdjaren, 18821901', Bulletin van de Oudheidkundige Kring “De Vier Ambachten" 29-1 (2010), pp. 14-17.

'Een Steense meester in wording (deel 2). Imandt tekent voor de Oost, 1901-1908', Bulletin van de Oudheidkundige Kring "De Vier Ambachten" 28-3 (2009), pp. 7-10.

, 'Een Steense rat in de Oost. W.J.F. Imandt (1882-1967)', Zeeuws

Tijdschrift 48-4 (1998), pp.15-23.

\section{Archief}

Koninklijke Bibliotheek 's Gravenhage. Collectie W. Witsen, 75C51, Brief van I. Israëls aan W. Witsen van 17 juli 1922 , Solo.

\section{Noten}

1. Fotografie: Anda van Riet

2. De Loos Haaxman 1968: 98.

3. Van Brakel 2004: 14.

4. Ibid.

5. Tielrooy 1930: 1.

6. Imandt 1926: 338.

7. Van der Velde 2010 en 2011.

8. De Taak, 8 december 1917.

9. De Reflector 4 (1919) 38: 754.

10. Imandt 1926: 338.

11. Weekblad voor Indië 16 (1919).

12. Javabode, 9 augustus 1920.

13. Koninklijke Bibliotheek. Correspondentie W. Witsen, 75C51.

14. Javabode, 12 april 1923.

15. Het Vaderland, 1 juni 1929.

16. Anoniem. Begeleidende tekst bij tentoonstellling.

17. Van Brakel 2009: 59.

18. Imandt 1926: 339. 